\title{
PENYIDIKAN TINDAK PIDANA YANG DILAKUKAN ANAK DI BAWAH UMUR MENURUT UNDANG-UNDANG NOMOR 35 TAHUN 2014 TENTANG PERLINDUNGAN ANAK
}

\author{
MADE DIKA NANDA ${ }^{1)}$, HJ. RINA SUWASTI' ${ }^{2)}$ \\ 1). Alumnus, ${ }^{2)}$ Staf Pengajar Fakultas Hukum UNMAS Mataram \\ e-mail: ${ }^{2)}$ rinapancaka@gmail.com
}

\section{ABSTRAK}

Di jaman sekarang kejadian tindak pidana, tidak saja dilakukan oleh orang dewasa, juga menyasar pada anak-anak di bawah umur. Hal ini banyak factor penyebabnya baik dari dalam keluarga, factor social, ekonomi, penggunaan teknologi sampai factor lingkungan dan lain-lain yang mempengaruhinya.

Perlindungan Anak adalah segala kegiatan untuk menjamin dan melindungi Anak dan hak-haknya agar dapat hidup, tumbuh, berkembang, dan berpartisipasi secara optimal sesuai dengan harkat dan martabat kemanusiaan, serta mendapat perlindungan dan kekerasan dan diskriminasi. Oleh karena itu Perlindungan Anak sesuai dengan undang-undang No. 35 Tahun 2014 wajib mendapaatkan perlindungan hukum sebagai tersangka melakukan tindak pidana anak dibawah umur yaitu 12 Tahun sampai 18 Tahun, karena masa depan anak masih bisa diperbaiki untuk harapan bangsa dan negara.

Kata kunci : Tindak pidana, anak di bawah umur, perlindungan anak

\section{ABSTRACT}

In recent times the incidence of criminal offenses, not only carried out by adults, but also are done by minors. This causes many factors from within the family, social factors, economics, the use of technology to environmental factors, and others that influence it.

Child Protection is all activities to guarantee and protect children and their rights so that they can live, grow, develop, and participate optimally in accordance with human dignity, and receive protection from violence and discrimination. Therefore Child Protection in accordance with law No. 35 of 2014 is obliged to obtain legal protection as a suspect of committing criminal acts of underage children, namely 12 years to 18 years, because the future of children can still be improved for the hopes of the nation and state.

Keywords: Crime, minors, child protection

\section{PENDAHULUAN}

\section{Latar Belakang}

Kejahatan itu tidak memandang status sosial yaitu baik umur dan jabatan yang di emban atau dipikul seseorang dalam kehidupan bermasyarakat. Di jaman global dunia saat ini sangat maju di bidang media sosial atau dunia maya atau intrnet sangat transparan apapun kejadian yang ada di dunia cepat mendapat informasi atau berita dimasyarakat nasional maupun internasional. Lingkungan dan sekitarnya harus mawas diri artinya peka dalam situasi apabila ada kejadian- kejadian yang mencurigai disekitar kita yang tidak biasa sehari-hari yang kita alami dalam keadaan aman.Kita tidak boleh atau tidak peduli atau cuek disekitar tempat tinggal atau lingkungan yang tidak biasa kejadian-kejadian yang terjadi tingkah laku alam sekitar kita tempat tinggal.

Di jaman sekarang kejadian-kejadian perbuatan pidana yang dilakukan anak anak dibawah umur yang akibat atau efek dari media sosial yang canggih dan transfaran dan juga pergaulan sehari hari di lingkungan alam sekitarnya juga sangat mempengaruhi. Curiga itu harus ada pada anak-anak di dalam keluarga kita dan lingkungan tempat tinggal kita artinya tingkah laku yang tidak biasa dilakukan anak di bawah umur dalam seharian pergaulan yang normal setara dengan anak-anak semasa bermain. Karena anak adalah Anugerah dari Tuhan Yang Maha Kuasa dan pewaris tahta dalam keluarga dan juga sebagai penerus generasi bangsa 
Indonesia, kita sebagai orang tua atau keluara harus menjaga martabat dari sebuah keluarga untuk masa depan anak jangan sampai ternoda akibat canggihnya media sosial atau dunia maya atau internet yang sangat transparan bisa melakukan perbuatan pidana atau tindak pidana tanpa sadar akibat dari perbuatan tersebut yang berakibat pada korban perlakuan tersebut dari perbuatan tersebut sangat fatal dari yang yang melakukan atau pelaku tetap diberikan ganjaran hukuman pidana sesuai Kiab Undang-undang Hukum Pidana Indonesia.

Tindak pidana merupakan suatu gejala yang tidak bisa lepas dari kehidupan manusia, karena perbuatan pidana selalu mengikuti perkembangan hidup manusia "Perbuatan pidana atau Tindak kriminal merupakan salah satu bentuk dari prilaku menyimpang yang selalu ada dan melekat pada tiap atau bentuk masyarakat, dengan kata lain tidak ada masyarakat yang sepi dari tindak pidana". Tindak pidana yang benar- benar terjadi di masyarakat sebenamya jauh lebih banyak dari pada yang diketahui yang ditangani oleh aparat penegak hukum. Tindak pidana dari waktu ke waktu selalu mengalami peningkatan baik dari kualitas maupun dari segi kuantitas hasil tindak pidanannya, aneka ragam tindak pidana semakin berkembang mengikuti perkembangan teknologi dan zaman, hal ini dapat dilihat pada tindak pidana ekonomi, tindak pidana dunia maya atau internet, juga tindak pidana modern lainnya hal ini dapat di lihat pada tindak pidana ekonomi, tindak pidana dapat dilihat dunia maya atau internet, juga tindak pidana modern lainnya.

Tindak pidana berasal dari manusia hidup dalam masyarakat dan timbul serta berkembang dalam masyarakat, maka dalam usaha penanggulaannya masyarakat harus di ikut sertakan sertakan sehingga timbul daya kemampuan untuk menanggulangi terjadinya tindak pidana, dengan demikian penanggulangan tindak pidana bukan tugas dan tanggung jawab pemerintah saja, tetapi merupakan suatu kegiatan yang terpadu antara aparat permerintah dan kekuatan sosial dalam masyarakat.

POLRI mempunyai tugas dan fungsi sebagai penjaga keamanan dan ketertiban dalam negeri sekaligus juga selaku Penyelidik dan Penyidik di dalam penegakan hukum, namun demikian tidak berate petugas Polri baik sebagai penjaga keamanan dan ketertiban maupun sebagai Penyidik dapat bertindak diluar aturan hukum yang berlaku.

POLRI sebagai penjaga ketertiban masyarakat selalu berpedoman pada Undang-undang nomer 2 tahun 2002 tentang Kepolisian Negara Republik Indonesia, Polri selaku penyelidik dan penyidik jika dalam melaksanakan tugasnya atau dalam kehidupan kesehariannya melakukan suatu perbuatan yang bertemangan dengan aturan hukum yang berlaku akan diambil tindak sesuai dengan PP Nomer 3 Tahun 2003 yang mengatur tentang Pelaksanaan Tehnis Institusional Peradilan Umum Bagi Anggota POLRI

Aparat pemerintah yang paling berkornpeten dalam hal penanggulangan suatu tindak pidana adalah Polisi. Dalam penanggulangan tindak pidana, Polisi menggunakan asas Crime Prevenlion (pencegahan kejahatan). Azas ini mendapatkan perhatian dan diterima oleh Polisi.Hal ini terbukti dengan adanya seksi pembinaan masyarakat (Binmas) yang bertugas memberikan penyuluhan dan penerangan kepada masyarakat luas tentang suatu tindak pidana sesuai dengan peraturan perundang-undangan yang berlaku, sehingga diharapkan dengan mengertinya masyarakat akan bahaya suatu tindak pidana, maka dapat dicegah suatu tindak pidana sedini mungkin.

Apabila ada laporan atau pengaduan seseorang atau masyarakat tentang adanya suatu tindak pidana yang dilakukan oleh seseorang atau sekelompok orang, maka Polisi wajib menindak lanjuti laporan atau pengaduan tersebut, dengan melakukan tindakan penyelidikan untuk menyelidiki kejadian yang dilaporkan tersebut guna menentukan apakah kejadian tersebut merupakan tindak pidana atau bukan, selanjutnya apabila dari hasil penyelidikan Polisi dapat menentukan laporan kejadian tersebut merupakan tindak pidana, maka Polisi meningkatkan tinkannya kepada tindakan penyidikan untuk mencari bukti-bukti, saksi dan tersangkanyadalam hal pencarian bukti,saksi dan tersangkanya diperlukan upayapaksa berupa penangkapan, untuk bisa terlaksana tindakan tersebut maka polisi harus mempunyai bukti permulaan yang cukup.

\section{Rumusan Masalah}

1. Bagaimanakah proses teknik dan taktik yang dilakukan oleh penyidik untuk pemeriksaan tersangka yang melakukan tindakan pidana dibawah umur.

2. Sejauh mana perlindungan hukum bisa diterapkan atau dilaksanakan seorang tersangka yang masih dibawah umur, telah melakukan tindak pidana 


\section{Tujuan dan Manfaat Penelitian}

Penelitian ini bertujuan untuk mengetahui : (a) bagaimanakah proses dan taktik yang dilakukan oleh penyidik untuk pemeriksaan tersangka yang melakukan tindakan pidana dibawah umur (b). sejauh mana perlindungan hukum bisa diterapkan atau dilaksanakan seorang tersangka yang masih dibawah umur, telah melakukan tindak pidana.

Penelitian ini diharapkan bermanfaat untuk memberikan bekal pengetahuan dalam mengkaji atau menerapkan suatu ilmu pengetahuan hukum khususnya hukum pidana, hukum acara pidana, melalui suatu tindakan empiris di lapangan/masyarakat. Sedangkan secara praktis, bahwa hasil peneltian ini akan dapat dimanfaatkan sebagai suatu masukan atau sumbangan pemikiran bagi pejabat / aparat terkait untuk meningkatkan kualitas pelaksanaan tugas, khususnya dalam penerapan peraturan hukum yang berlaku bagi kasus-kasus serupa.

\section{METODE PENELITIAN}

Jenis Penelitian ini merupakan penelitian normatif-empiris yang dilaksanakan diwilayah hukum POLRES Mataram. Penelitian ini menggunakan orang kunci yaitu orang yang benar mengetahui permasalahannya, selain itu juga dengan sampel anak dibawah umur yang memiiki kasus tindak pidana

Pengunmpulan data melalui wawancara, dengan menngunakan daftar pertanyaan yang telah disiapkann dan data terkumou dianaisis deskriptif kualitatif, yaitu dengan menjelaskan atau menggambarkan sesuatu yang diperoleh dari teori maupun dari hasil seleksi kemudian dihubungkan dengan peraturan hukum yang ada, sehingga mendapatkan jawaban dari permasalahan yang diteliti

\section{HASIL DAN PEMBAHASAN}

\section{Proses Pemeriksaan Penyidik Dalam Mengintrogasi Tersangka Anak Di bawah Umur Dalam Tindak Pidana.}

Tindak pidana anak dibawah umur adalah berasal dari manusia yang hidup dalam masyarakat dan timbul serta berkembang dalam masyarakat, maka untuk usaha penanggulangannya, masyarakat harus diikutsertakan sehingga akan timbul suatu daya kemampuan masyarakat untuk menanggulangi kejahatan, tindak pidana anak dibawah umur, karena kejahatan bukan tugas dan tanggung jawab pemerintah saja, akan tetapi merupakan suatu kegiatan yang terpadu antara aparat pemerintah dengan kekuatan sosial dalam masyarakat.

Proses Pemeriksaan merupakan kegiatan untuk mendapatkan keterangan kejelasan yang keidentifikasi dengan tersangka atau saksi-saksi serta barang bukti maupun dalam unsur-unsur tindak pidana yang telah terjadi, sehingga kedudukan atau peranan seseorang penyidik maupun barang bukti di dalam tindak pidana tersebut menjadi jelas dan dituangkan didalam Berita Acara Pemeriksaan, yang berwenang melakukan pemeriksaan adalah Penyidik atau Penyidik Pembantu.Pemeriksaan dilakukan atas dasar :

1. Laporan Polisi.

2. Laporan hasil penyelidikan yang dibuat oleh petugas atas perintah Penyidik atau Penyidik Pembantu.

3. Berita Acara Pemeriksaan di TKP (tempat kejadian perkara), penangkapan, penahanan, penggeledahan dan penyitaan.

4. Petunjuk dari Penuntut Umum untuk melakukan pemeriksaan tambahan.

5. Dalam hal saksi/tersangka berada diluar wilayah hukum Penyidik/Penyidik Pembantu yang melakukan penyidikan, dapat meminta bantuan Penyidik/Penyidik Pembantu dari kesatuan dimana saksi/tersangka berada.

Cara atau tekhnik pemeriksaan dapat menggunakan :

1. Interview adalah usaha atau kegiatan untuk memperoleh keterangan dari orang yang memiliki atau diduga memiliki keterangan.

2. Interogasi adalah melakukan pemeriksaan terhadap tersangka atau saksi dengan pertanyaan - pertanyaan secara linsan atau tertulis untuk memperoleh keterangan dalam rangka mengungkap kejahatan.

3. Konfrontasi adalah tehnik pemeriksaan dalam rangka penyidikan dengan cara mempertemukan orangorang yang bertindak sebagai saksi atau tersangka untuk menguji kebenaran, persesuaian atau bahkan perbedaan keterangan untuk dituangkan dalam berita acara konfrontasi.

4. Rekontruksi adalah visualisasi kejadian perkara yang diperagakan kembali berdasarkan segala data dan fakta yang diperoleh sebagai hasil penyidikan, guna meyakinkan kebenaran hasil penyidikan, yaitu 
dengan memberikan kesempatan kepada tersangka memperagakan kembali tindakan pidana yang telah dilakukan ditempat kejadian perkara.

Sebelum dimulainya pemeriksaan, penyidik wajib memberitahukan hak tersangka untuk mendapatkan bantuan hukum atau dalam perkara tertentu sebagaimana dimaksud dalam Pasal 56 ayat (1) KUHAP berbunyi:

"Dalam hal tersangka atau terdakwa disangka atau didakwa melakukan tindak pidana yang diancam dengan pidana mati atau ancamanlima belas tahun atau lebih atau bagi mereka yang tidak mampu yang diancam dengan pidana lima tahun atau lebih yang tidak mempunyai penasehat hukum sendiri, pejabat yang bersangkutan pada semua tingkat pemeriksaan dalam proses peradilan wajib menunjuk penasehat hukum bagi mereka".

Apabila tersangka adalah anak dibawah umur maka dalam pemeriksaan berpedoman pada Undangundang Nomor 3 Tahun 1997 tentang Peradilan Anak. Pada waktu Penyidik/Penyidik Pembantu sedang melakukan pemeriksaan terhadap tersangka, penasehat hukum dapat mengikuti jalannya pemeriksaan dengan cara melihat dan mendengar pemeriksaan, kecuali dalam hal kejahatan terhadap keamanan negara, penasehat hukum tidak dapat mendengar pemeriksaan terhadap tersangka.

Dalam pelaksanaan pemeriksaan, pemeriksa menggunakan Bahasa yang jelas dan mudah dimengerti dan tersangka berhak diberitahukan kepada apa yang dipersangkakan kepadanya pada saat pemeriksaan dimulai. Dalam pemeriksaan ditanyakan pula apakah tersangka menghendaki didengarnya saksi yang menguntungkan, dan bilamana ada maka Penyidik/Penyidik Pembantu wajib memanggil dan memeriksa saksi tersebut. Pada waktu dilakukan pemeriksaan, dilarang menggunakan kekerasan atau penekanan dalam bentuk apapun dan pemeriksaan selalu berpedoman pada peraturan yang berlaku.

Apabila pemeriksaan dianggap sudah selesai maka hasil pemeriksaan sebelum ditanda tangani hares dibaca terlebih dahulu oleh tersangka, apabila hasil pemeriksaan tersebut sudah sesuai dengan yang disangkakan, dan sudah tidak ada lagi yang perlu ditulis dalam berita acara, barulah berita acara pemeriksaan tersebut ditanda tangani baik oleh tersangka, penyidik maupun penasehat hukumnya dan penterjemah bahasa (bila melibatkan penterjemah bahasa). Untuk pemeriksaan saksi, yang dapat diperiksa adalah orang yang melihat, mendengar, mengetahui atau mengalami sendiri secara langsung suatu tindak pidana. Pendapat maupun rekaan yang diperoleh dan hasil pemikiran seseorang bukan merupakan keterangan saksi. Keterangan saksi yang satu dengan yang lain mempunyai nilai kebenaran apabila memiliki persesuaian.

Untuk pemeriksaan informasi selalu dihindari terjadinya konflik antara pemeriksa dengan tersangka atau terdakwa, akan menimbulkan rasa simpati agar saksi bersedia memberikan keterangan yang lebih jelas dan lengkap, kepada saksi yang diduga cukup alasan tidak dapat hadir dalam persidangan di Pengadilan dapat dilakukan penyumpahan atau mengucapkan janji, baik sebelum atau sesudah memberikan keterangan.Pemeriksaan terhadap saksi yang berada di luar negeri berpedoman pada buku petunjuk pelaksanaan tentang Pemeriksaan.

Berita Acara Pemeriksaan saksi ditanda tangani oleh Penyidik/Penyidik Pembantu dan saksi serta penterjemah bahasa bila diperlukan. Dalam hal penyidik memerlukan keterangan ahli, penyidik dapat meminta bantuan seseorang yang memiliki keahlian khusus tentang hal yang diperlukan untuk membuat terang suatu perkara pidana guna kepentingan pemeriksaan. Sebelum diperiksa, seorang ahli wajib mengangkat sumpah atau mengucapkan janji di muka penyidik bahwa ia akan memberikan keterangan menurut pengetahuannya yang sebaik-baiknya, kecuali bila disebabkankarena harkat serta martabat pekerjaan atau jabatannya yang mewajibkan is menyimpan rahasia dapat menolak untuk memberikan keterangan yang diminta.Pengambilan sumpah atau janji dilaksanakan oleh penyidik sesuai dengan peraturan perundang-undangan tentang sumpah atau janji, baik mengenai isinya maupun tata caranya. Penyidik dapat mengajukan permintaan keterangan ahli kepada ahli kedokteran kehakiman atau dokter dan atau ahli lainnya untuk melakukan pemeriksaan korban yang luka atau keracunan ataupun mati serta terhadap benda/barang bukti dan hal-hal lain yang berkaitan dengan keahliannya. Keterangan atau informasi yang diberikai oleh ahli sebagaimana tersebut diatas dapat memberikan Berita Acara atau keterangan tertulis.

Hal-hal perlu diperhatikan dalam pemeriksaan :

1.Disediakan ruangan yang memenuhi persyaratan untuk pelaksanaan kegiatan pemeriksaan dan dapat menampung kebutuhan bantuan hukum bagi tersangka tanpa menggangu kelancaran jalannya pemeriksaan. 2. Tersangka atau saksi yang diperiksa harus dalam keadaan sehat jasmani dan rohani.

3. Dalam hal tersangka tidak bersedia menanda tangani Berita Acara Pemeriksaan, hal tersebut dicatat dalam

Berita Acara Pemeriksaan dengan menyebutkan alasan serta penyidik/Penyidik Pembantu membuat Berita Acara Penolakan Tanda Tangan.

4.Dalam hal pemeriksaan terhadap wanita agar diperhatikan norma-norma kesusilaan dan agama.

5.Memperhatikan dan melindungi hak asasi seseorang dengan tidak mempublikasikan keterangan 
tersangka/saksi atau ahli sesuai asas praduga tak bersalah.

\section{Bentuk Perlindungan Hukum terhadap Anak Sebagai Tersangka}

Perlindungan adalah pemberian jaminan atas keamanan, ketenteraman, kesejahteraan dan kedamaian dan pelindung atas segala bahaya yang mengancam pihak yang dilindungi. Perlindungan hukum adalah hal perbuatan melindungi menurut hukum. Liii Rasjidi dan I.B. Wyasa Putra mengemukakan bahwa hukum dapat difungsikan tidak hanya mewujudkan kepastian, tetapi jugajaminan perlindungan dan keseimbangan yang sifatnya tidak sekedar adaptif dan fleksibel, namun juga predildif dan antisipatif. ${ }^{12}$ Sebagaimana dijelaskan oleh Suriaryati Hartono, dapat pula difungsikan untuk menciptakan keseimbangan baru antara kepentingan konsumen, para pengusaha, masyarakat dan pemerintah, oleh karena keseimbangankeseimbangan lama telah mengalarni perombakan dan perubahan. Hukum terutama dibutuhkan oieh mereka yang lemah dan belum kuat secara sosial, ekonomi dan politik.

Menurut Undang-Undang RI No. 35 Tahun 2014, Pasal 2, Bab II Asas dan Tujuannya adalah bahwa : Penyelenggaraan perlindungan anak beradsaskan Pancasila dan berlandaskan Undang-Undang Dasar Negara Republik Indonesia Tahun 1945 serta prinsip-prinsip dasar Konvensi Hak-Hak Anak meliputi: a). non diskriminasi; b).kepentingan yang terbaik bagi anak; c).hak untuk hidup, kelangsungan hidup, dan perkembangan; dan d).penghargaan terhadap pendapat anak

Pasal 3 meliputi Perlindungan anak bertujuan untuk menjamin terpenuhinya hak-hak anak agar dapat hidup, tumbuh, berkembang, dan berpartisipasi secara optimal sesuai dengan harkat dan martabat kemanusiaan, serta mendapat perlindungan dan kekerasan dan diskriminasi, demi terwujudnya anak Indonesia yang berkualitas, berakhlak mulia, dan sejahtera.

Perlindungan Hukum terhadap Anak mencapai umur 12 (dua belas) tahun tetapi belum mencapai 18 (delapan belas) tahun dan belurn pemah kawin yang melakukan tindak pidana atau melakukan perbuatan yang dinyatakan terlarang bagi anak, sesuai dengan ketentuan Pasal 1 angka 2 yang telah direvisi oleh Mahkamah Konstiusi Undang-Undang No.3 tahun 1997 tentang Pengadilan Anak. Perlindungan Anak adalah segala kegiatan untuk menjamin dan melindungi Anak dan hak-haknya agar dapat hidup, tumbuh, berkembang, dan berpartisipasi secara optimal sesuai dengan harkat dan martabat kemanusiaan, serta mendapat perlindungan dan kekerasan dan diskriminasi.

Keluarga adalah unit terkecil dalam masyarakat yang terdiri atas suami istri, atau suami istri dan anaknya, atau ayah dan anaknya, atau ibu dan anaknya, atau keluarga sedarah dalam garis lurus ke atas atau ke bawah sampai dengan derajat ketiga. Dalam proses pemeriksaan yang dilakukan penyidik si anak melakukan tindak pidana selalu didampingi komisi perlindungan anak (KPPA) ini dalam prakteknya." Eka Dian Ganit KPA Polres Mataram.

Untuk si anak yang supaya menjaga mental si anak tidaka takut waktu proses pemeriksaan penyidik, dan sebgai penyidik sangat hati-hati supaya tidak melanggar HAM (Hak Asasi Manusia) si anak sebgai tersangka. Walaupun si anak melakukan tindak pidana sebgai tersangka mendapatkan perlindungan hukum sesuai dengan UU RI no. 35 tahun 2014 , BAB I Pasal 1 Butir (15) yaitu Perlindungan khusus adalah perlindungan yang diberikan kepada anak dalam situasi darurat, anak yang berhadapan dengan hukum, anak dari kelompok minoritas dan terisolasi, anak yang dieksploitasi secara ekonomi dan/atau seksual, anak yang diperdagangkan, anak yang menajdi korban penyalahgunaan narkotika, alcohol, psikotropika, dan zat adiktif lainnya (Napza), anak korban penculikan, penjualan, perdagangan, anak korban kekerasan baik fisik dan/atau mental, anak yang menyandang cacat, dan anak korban perlakuan salah dan penelantaran.

\section{SIMPULAN DAN SARAN}

\section{Simpulan}

1. Teknik yang dilakukan oleh penyidik didalam pemeriksaan tersangka pada tingkat penyidikan, seorang penyidik tentunya memahami teknik teknik sendiri dan selalu berpedoman kepada peraturan peraturan dan perundang undangan yang berlaku dengan menggunakan tata Bahasa yang mudah dimengerti karena didalam pemeriksaan bertujuan untuk menggali agar yang diperiksa dapat mengakui tentang perbuatan yang mereka lakukan, begitu juga agar didapat barang bukti yang berhubungan dengan perbuatan yang dilakukan, sehingga seorang penyidik diperlukan keahlian dan professional didalam melakukan penyidikan agar tidak menyimpang dengan peraturan perundang-undangan untuk menghindari hal-hal yang tidak diinginkan terhadap petugas penyidik : karena untuk bisa terungkapnya pengakuan tersangka sangat diperlukan bagi penyidik keuletan, ketelitian, kejelian dan keahlian didalam mengarahkan keterangan tersangka,sebab tersangka yang melakukan tindak pidana masih dibawah umur, suatu proses 
beradaptasi dengan mental anak-anak dibawah umur menurut katogori Undang-Undang Perindungan Anak Nomor 35 Tahun 2014. Dan tidak melanggar hak azasi si anak tersebut sebagai tersangka sudah melakukan suatu tidak pidana.

2. Sesuai dengan undang-undang No. 35 Tahun 2014 tentang Perlindungan Anak wajib mendapaatkan perlindungan hukum yang sesuai dengan undang-undang tersebut sebagai tersangka melakukan tindak pidana anak dibawah umur yaitu 12 Tahun sampai 18 Tahun, Bagaimanapun masa depan anak tersebut masih diperbaiki harapan bangsa dan negara.

\section{Saran-Saran}

1. Seluruh aparat penegak hukum harus mampu meningkatkan wawasan dan profesionalismenya dalam suatu penegakan hukum agar penyelesaian proses perkara pidana terutama dalam penyidikan dapat diselesaikan tanpa melanggar hak-hak asasi manusia dan menciptakan keadilan sesuai harapan masyarakat serta mampu menerapkan asas peradilan cepat, sederhana, dan biaya murah.

2. Hendaknya dapat dihadirkan penasehat hukum dalam setiap pemeriksaan perkara pidana pada tingkat penyidikan, agar kebenaran materiil sejauh mungkin dapat terwujud, guna perlingdungan hak asasi tersangka atau terdakwa dibawah umur dan perlindungan kepentingan lain yang lebih luas, seperti korban negara dan masyarakat.

\section{DAFTAR PUSTAKA}

Abdurrachman, 1980. Pembaharuan Hukum Acara Pidana, Alumni, Bandung

Anonim, 2002. Undang - Undang Republik Indonesia Nomor 8 Tahun 1981 Tentang Hukum Acara Pidana. Sinar Grafika, Jakarta. 2014. Perlindungan Anak,UU RI No. 35 Tahun 2014,Sinar Grafika, Jakarta

Atmasasmita Romli, 1982. Bunga rampai Hukum Acara Pidana, Sinar Grafika, Jakarta

Bawengan, 1988. Masalah Kejahatan Dengan Sebab dan Akibat, Pradnya Pramita Jakarta

Hamzah Andi, 1985. Pengantar Hukum Acara Pidana Indonesia, Ghalia Indonesia, Jakarta

Husein Harun, 1991. Penyidikan dan Penuntutan Dalam Proses Pidana, Rineka Cipta,Jakarta

Harahap Yahya, 2002. Pembahsan Permasalahan dan Penerapan KUHAP Mid Sinar Grafika, Jakarta

Lamintang, 1984. KUHAP dan Pembahasan Secara Yuridis Menurut yurisprudensi dan Ilmu Pengetahuan Hukum Pidana, Sinar Baru, Bandung

Mulyadi Lilik, 2002. Hukum Acara Pidana, PT, Citra Aditya Bakti

Rahardjo Satjipto, 1988. Citra Polisi, Yayasan Obor, Jakarta

Soesilo, 1984. Pengetahuan Hukum di Indonesia, Djambatan, Jakarta

Saddli Saparinah, 1982. Persepsi Sosial Menganai Perilaku Menyimpang, Bulan Bintang Jakarta, 